\title{
Article \\ Chloroplast DNA Diversity in Populations of $P$. sylvestris L. from Middle Siberia and the Romanian Carpathians
}

\author{
Marina Sheller ${ }^{1,2,3, *}$, Elena Ciocîrlan ${ }^{3}\left(\mathbb{D}\right.$, Pavel Mikhaylov ${ }^{1}\left(\right.$, Sergey Kulakov ${ }^{1,4}$, Nadezhda Kulakova ${ }^{1}$, \\ Aleksey Ibe ${ }^{2}$, Tatyana Sukhikh ${ }^{2}$ and Alexandru Lucian Curtu ${ }^{3}$ (D) \\ 1 Scientific Laboratory of Forest Health, Reshetnev Siberian State University of Science and Technology, \\ 660037 Krasnoyarsk, Russia; mihaylov.p.v@mail.ru (P.M.); hbz_sibstu@mail.ru (S.K.); \\ Nadezhda21@mail.ru (N.K.) \\ 2 Department of Monitoring of Forest Genetic Recourses, Branch of the Russian Centre of Forest \\ Health-Centre of Forest Health of Krasnoyarsk krai, 660036 Krasnoyarsk, Russia; aaibis@mail.ru (A.I.); \\ cherkesova-tv@yandex.ru (T.S.) \\ 3 Faculty of Silviculture and Forest Engineering, Transilvania University of Brasov, 500123 Brasov, Romania; \\ ciocirlan.elena@unitbv.ro (E.C.); lucian.curtu@unitbv.ro (A.L.C.) \\ 4 Sukachev Institute of Forest SB RAS, Federal Research Center "Krasnoyarsk Science Center SB RAS", \\ 660036 Krasnoyarsk, Russia \\ * Correspondence: maralexsheller@mail.ru
}

Citation: Sheller, M.; Ciocîrlan, E.; Mikhaylov, P.; Kulakov, S.; Kulakova, N.; Ibe, A.; Sukhikh, T.; Curtu, A.L. Chloroplast DNA Diversity in Populations of P. sylvestris L. from Middle Siberia and the Romanian Carpathians. Forests 2021, 12, 1757. https://doi.org/10.3390/f12121757

Academic Editor: Carol A. Loopstra

Received: 3 November 2021

Accepted: 10 December 2021

Published: 13 December 2021

Publisher's Note: MDPI stays neutral with regard to jurisdictional claims in published maps and institutional affiliations.

Copyright: (C) 2021 by the authors. Licensee MDPI, Basel, Switzerland. This article is an open access article distributed under the terms and conditions of the Creative Commons Attribution (CC BY) license (https:/ / creativecommons.org/licenses/by/ $4.0 /)$.

\begin{abstract}
Scots pine is one of the dominant conifer species in forest ecosystems of the boreal zone in Eurasia. Knowledge of the genetic structure and the level of genetic variability of Scots pine populations is relevant for the development of measures aimed at conservation of species' diversity. In this study, we used ten paternally inherited chloroplast microsatellite loci to investigate the genetic diversity of nineteen Scots pine populations from Middle Siberia and the Romanian Carpathians. The results of the study showed high genetic diversity $\left(H_{\mathrm{CP}}=0.91-1.00\right)$ in all of the investigated populations. The cpSSR analysis yielded a total of 158 haplotypes. The majority of the haplotypes (85\%) were detected only once (unique haplotypes). Three common haplotypes were found between the Carpathian and the Siberian populations of Scots pine. Analysis of molecular variance (AMOVA) showed that only $3 \%$ of the variation occurred among populations from Middle Siberia and 6\% of the variation existed among populations from the Carpathian Mountains. Overall, we found a weak geographic population structure in Scots pine from Middle Siberia and the Romanian Carpathians. The present study on genetic diversity in the Siberian and the Carpathian populations of Scots pine may contribute to the sustainable management and conservation of Scots pine genetic resources in Middle Siberia and the Romanian Carpathians.
\end{abstract}

Keywords: Scots pine; chloroplast DNA; relict populations; genetic diversity; Siberia; Carpathians

\section{Introduction}

Genetic diversity is the basis for biological stability; it allows species to evolve and to adapt to changing environmental conditions [1]. Knowledge of the genetic structure and the level of genetic variability of populations is relevant for the development of measures aimed at the conservation of species' genetic diversity [2].

Scots pine (Pinus sylvestris L.) is one of the keystone species in forest ecosystems of the boreal regions in Eurasia. It is of great ecological and economic importance and is adapted to a variety of environmental conditions [3,4]. Scots pine is a monoecious, wind-pollinated and predominantly outcrossing conifer [5-7]. It usually forms extensive pure forests or mixed stands with birch and other conifers [8].

In Russia, Scots pine is one of the main forest-forming tree species and it covers $15.6 \%$ of Russian forests [9]. A significant part of its distribution is located in Siberia, where it reaches the northern border of woody vegetation distribution (bog massifs in the West Siberian plain), the zone of dry steppes in the south (isolated groves in Altay, Khakassia, 
Tuva, and Buryatia regions) and rocky mountain slopes (Kuznetsk Alatau Mts. and the Sayan Mts.) [10-12]. In Siberia, Scots pine forests form a complex spatial mosaic, which is determined by an adaptive compromise of Scots pine among the phytocenotic competition with the other forest-forming species and its edaphic preferences. In the Angara River basin, Scots pine forms a continuous distribution range, occupying a variety of soils [12]. Long-term intensive exploitation of pine forests in Russia has led to their fragmentation across the whole territory $[13,14]$. Over the last decade, the area of Scots pine forests in Russia has decreased by 2 million ha [15]. Consequently, the characterization of the genetic variability of natural Scots pine populations in Russia is an important prerequisite for better use of their genetic resources in breeding and biodiversity conservation programs. Unlike Russia, where Scots pine has a vast distribution area, in Romania it occurs sparsely across the Eastern and Southern Carpathian Mountains, where a few relict populations still exist. These populations grow in ecologically extreme habitats, where a strong selection pressure is assumed [7]. Knowledge about the level of genetic diversity present in relict populations is important for preparing and implementing protective measures for these small and endangered populations of Scots pine in the Romanian Carpathians [16].

In recent years, different types of molecular markers have been used for the assessment of the genetic diversity and genetic structure in tree species [7,17-20]. Among them, chloroplast simple sequence repeats (a.k.a SSRs or microsatellites) are useful markers in population genetic diversity evaluation, population structure analysis and phylogenetic studies $[4,16,21-27]$. Chloroplast microsatellites are characterized by high polymorphism, uniparental inheritance, and a lack of sexual recombination [28]. For many years, chloroplast simple sequence repeats (cpSSRs) have been one of the tools used to characterize tree genetic resources, including Scots pine [29-32].

A number of studies, based on chloroplast microsatellites, have shown that the genetic variation of Scots pine is generally high and accumulated mainly within populations, while genetic differences among populations are fairly small $[4,5,21]$. This homogeneity appears particularly as an effect of common ancestry in a recent evolutionary history, as well as an extensive gene flow, especially through pollen. Since the pollen of Scots pine has a great mobility potential, the homogeneity could be easily maintained over long distances [33].

In this study, we used chloroplast microsatellite markers to characterize the level of genetic diversity of Scots pine populations in two geographic regions of its Eurasian natural range with different ecological settings and evolutionary history. Specifically, we aimed to address the following questions: (1) What is the pattern of genetic structure and diversity in Scots pine populations from Middle Siberia and the Romanian Carpathians? (2) How large is the degree of genetic differentiation between the two Scots pine distribution regions at the chloroplast DNA level?

\section{Materials and Methods}

\subsection{Plant Material}

Nineteen native populations of Scots pine were chosen within the natural distribution range of the species in Middle Siberia and the Romanian Carpathians (Table 1, Figure 1).

Scots pine is a dominant species in all studied populations. Four of them (Pop-A:Pop$D$,) are located in taiga forest zone, three (Pop-E:Pop-G) grow in forest-steppe zones and eight (Pop-H:Pop-O) are distributed in the Southern Siberian mountain zone [34]. Four relict populations of Scots pine (Pop-P:Pop-S) are located in the Southern and Eastern Carpathian Mountains. Ten adult trees were randomly chosen in each population. Consequently, the total number of analyzed individuals was 190. Needles collected from the trees were stored in silica gel until DNA extraction was carried out. 
Table 1. Geographical location of 19 Scots pine populations in Middle Siberia and the Romanian Carpathians.

\begin{tabular}{|c|c|c|c|c|c|}
\hline No. & $\begin{array}{l}\text { Population/Name/ } \\
\text { Federal Region }\end{array}$ & $\mathbf{N}$ & Forest Zone & Latitude/Longitude & $\begin{array}{l}\text { Altitude } \\
(\mathrm{m})\end{array}$ \\
\hline & Middle Siberia & & & & \\
\hline 1 & Pop-A/Vanavara_2/Krasnoyarsk krai & 10 & $\mathrm{~T}$ & $60.36 / 102.37$ & $260-270$ \\
\hline 2 & Pop-B/Vanavara_1/Krasnoyarsk krai & 10 & $\mathrm{~T}$ & $60.24 / 102.43$ & $350-360$ \\
\hline 3 & Pop-C/Chunoyar/Krasnoyarsk krai & 10 & $\mathrm{~T}$ & $57.44 / 97.37$ & $165-170$ \\
\hline 4 & Pop-D/Borzovo/Krasnoyarsk krai & 10 & $\mathrm{~T}$ & $57.17 / 97.27$ & $275-280$ \\
\hline 5 & Pop-E/Sukhobuzimskoye_2/Krasnoyarsk krai & 10 & Fs & $56.50 / 93.22$ & $155-160$ \\
\hline 6 & Pop-F/Sukhobuzimskoye_1/Krasnoyarsk krai & 10 & Fs & $56.30 / 92.97$ & $280-290$ \\
\hline 7 & Pop-G/Zeledeevo/Krasnoyarsk krai & 10 & Fs & $56.22 / 92.24$ & $325-330$ \\
\hline 8 & Pop-H/Uyar/Krasnoyarsk krai & 10 & SSm & $55.89 / 93.82$ & $360-370$ \\
\hline 9 & Pop-I/Shalo/Krasnoyarsk krai & 10 & SSm & $55.76 / 93.76$ & $340-350$ \\
\hline 10 & Pop-J/Narva/Krasnoyarsk krai & 10 & SSm & $55.45 / 93.73$ & $360-380$ \\
\hline 11 & Pop-K/Sarala_2/Republic of Khakassia & 10 & SSm & $55.00 / 89.40$ & $550-560$ \\
\hline 12 & Pop-L/Sarala_1/Republic of Khakassia & 10 & SSm & $54.87 / 89.22$ & $500-520$ \\
\hline 13 & Pop-M/Yrban/Republic of Tuva & 10 & SSm & $52.72 / 95.74$ & $860-980$ \\
\hline 14 & Pop-N/Balgazyn_1/Republic of Tuva & 10 & SSm & $51.08 / 95.09$ & $970-1060$ \\
\hline 15 & $\begin{array}{c}\text { Pop-O/Balgazyn_2/Republic of Tuva } \\
\text { Romanian Carpathians }\end{array}$ & 10 & SSm & $51.02 / 95.28$ & $880-890$ \\
\hline 16 & Pop-P/Poiana Stampei & 10 & $\mathrm{ECm}$ & $47.30 / 25.12$ & 920 \\
\hline 17 & Pop-Q/Cheile Bicazului & 10 & $\mathrm{ECm}$ & $46.83 / 25.80$ & $1060-1110$ \\
\hline 18 & Pop-R/Retezat & 10 & $\mathrm{SCm}$ & $45.44 / 22.78$ & $680-750$ \\
\hline 19 & Pop-S/Lotrişor & 10 & $\mathrm{SCm}$ & $45.30 / 24.28$ & $340-510$ \\
\hline
\end{tabular}

Note: Sample size (N); Taiga forest zone (T); Forest-steppe zone (Fs); Southern-Siberian mountain zone (SSm); Southern Carpathian Mountains (SCm); Eastern Carpathian Mountains (ECm).
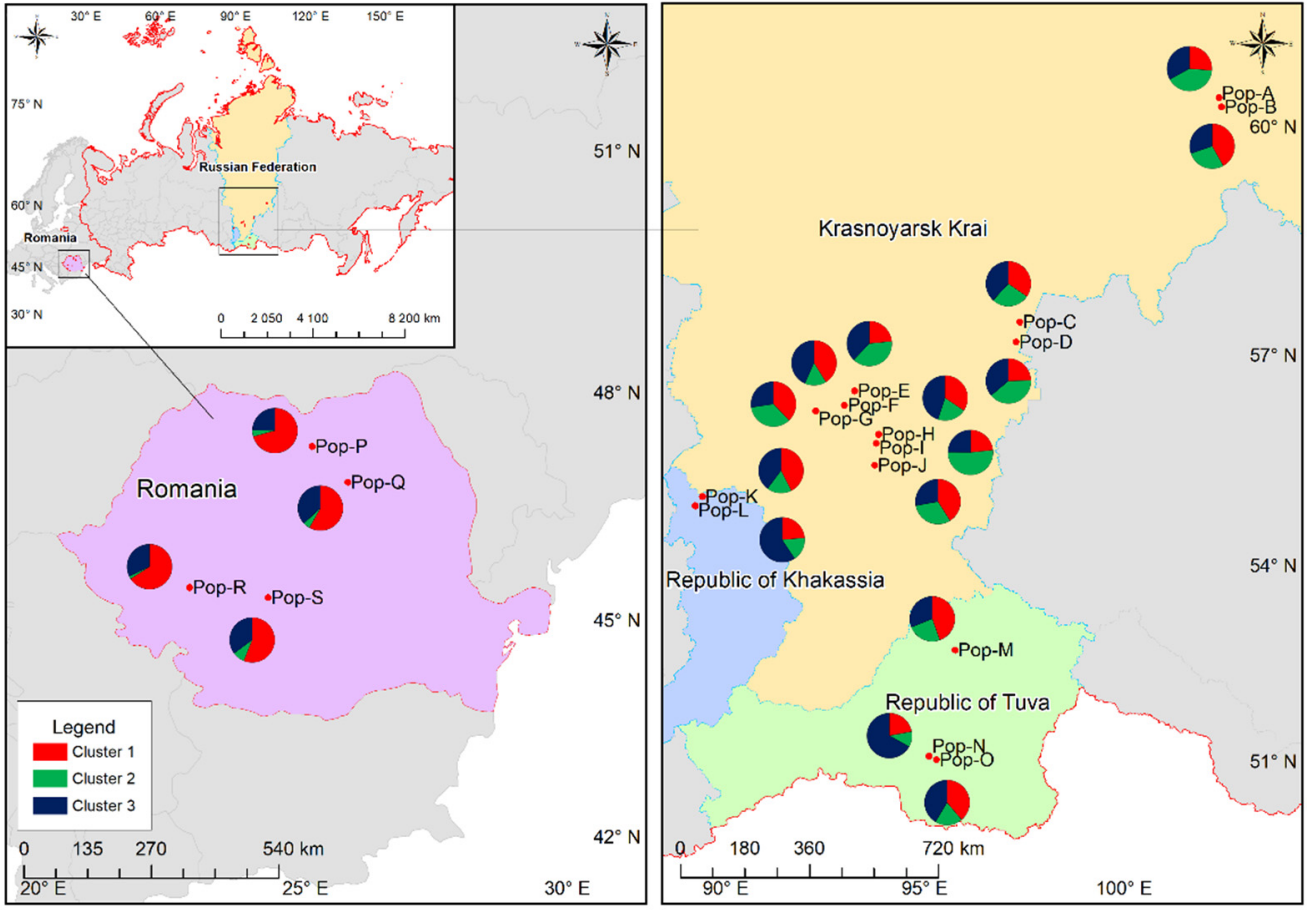

Figure 1. Geographical location of the studied Scots pine populations in Middle Siberia and the Romanian Carpathians (for the abbreviations, see Table 1). Populations of Scots pine are indicated by red dots. The sector maps show the mean cluster membership proportions of the analyzed individuals in each of the 19 Scots pine populations based on the genetic structure at $K=3$.

\subsection{Molecular Analysis}

Genomic DNA was extracted from dried needles with the CTAB method [35]. The quality and concentration of the extracted DNA were measured with a Nanodrop 8000 spec- 
trophotometer (Thermo Fisher Scientific, Waltham, MA, USA), then diluted to a concentration of 10-20 ng/ $\mu \mathrm{L}$. Ten chloroplast microsatellite markers were chosen for the genetic analysis: PCP45071, PCP36567, PCP48256, PCP41131, PCP30277, PCP26106, Pt1254, Pt15169, Pt71936, and Pt7268 [28,29]. The cpSSR loci were amplified in two PCR multiplex reactions in a total volume of 10-12 $\mu \mathrm{L}$ using Qiagen Multiplex PCR Kits (Qiagen, Hilden, Germany) under conditions recommended by the manufacturer. PCR amplification was performed in a Corbett thermal cycler (Corbett Research, Mortlake, NSW, Australia) with the following conditions: an initial denaturation of $15 \mathrm{~min}$ at $95^{\circ} \mathrm{C}$, then 30 cycles of $15 \mathrm{~s}$ at $94{ }^{\circ} \mathrm{C}$, $1 \mathrm{~min} 30 \mathrm{~s}$ at $60{ }^{\circ} \mathrm{C}$ (for the set of $6 \mathrm{PCP}$ loci) and $58^{\circ} \mathrm{C}$ (for the set of $4 \mathrm{Pt}$ loci), $1 \mathrm{~min} 30 \mathrm{~s}$ at $72{ }^{\circ} \mathrm{C}$, and a final extension of $10 \mathrm{~min}$ at $72{ }^{\circ} \mathrm{C}$. Amplified fragments were analyzed on a GenomeLab GeXP Genetic Analyzer (Beckman Coulter, Fullerton, CA, USA) with an internal size standard. Fragment sizing was performed using the GenomeLab GeXP software (Version 10.2, Beckman Coulter, Fullerton, CA, USA).

\subsection{Statistical Analysis}

POPGENE ver. 1.31 [36] and GenAlEx v. 6.5 [37] were used to estimate the following genetic diversity parameters: the observed number of alleles per locus $(\mathrm{Na})$; the mean number of effective alleles $(\mathrm{Ne})$; Shannon's Information index $(I)$; Nei's gene diversity index $(H)$; Gene flow $(\mathrm{Nm})$; haploid genetic diversity $(h)$.

Chloroplast DNA haplotypes were determined as a combination of the different microsatellite variants across the ten cPSSR loci. HAPLOTYPE ANALYSIS ver. 1.05 [38] was used to estimate the number of different haplotypes $(A)$, number of private haplotypes $(P)$, the effective number of haplotypes $\left(N_{E}\right)$, the haplotype diversity $\left(H_{C P}\right)$, and the mean genetic distance between haplotypes $\left(D^{2} \mathrm{sh}\right)$.

The unweighted pair-group method with arithmetic mean (UPGMA) was used to perform a cluster analysis on the Nei's genetic distances data [39] and STATISTICA software v.8 was used to build a tree diagram [40].

Analysis of the molecular variance (AMOVA) and the Mantel test were performed using GenAlEx v. 6.5 [37]. The statistical significance of the AMOVA and Mantel test were determined for all populations and loci, with the number of permutations set to 999 .

Population structure was analyzed using STRUCTURE ver.2.3.4 with a Bayesian clustering approach [41]. Testing ten independent runs with K from 1 to 19, each run had a burn-in period of 50,000 iterations and 100,000 Monte Carlo Markov iterations, assuming no admixture model, correlated allele frequencies, and no prior information on the sampling location. The studied populations were separated into groups by the Structure Harvester program [42], based on $\Delta \mathrm{K}$ values [43].

\section{Results}

\subsection{Microsatellite Analysis}

In total, 49 alleles were observed at ten cpSSR loci across all 190 individuals in the nineteen populations of Scots pine (Table 2). Two loci, PCP45071 and the Pt71936, showed the largest number of alleles, while the locus Pt15169 showed the highest values for Ne (3.97), $I$ (1.53), and $h(0.75)$. The mean $I, H$, and $N m$ values were $0.94(0.46-1.53), 0.49$ (0.20-0.75), and 3.40 (2.04-6.16), respectively (Table 2).

The mean number of alleles and effective number of alleles were slightly lower in the Siberian populations $(\mathrm{Na}=2.64 ; \mathrm{Ne}=1.95)$ when compared with the Carpathian $(\mathrm{Na}=2.73 ; \mathrm{Ne}=2.08)$ (Table 3). The $I$ ranged from 0.38 (Pop-N) to 0.88 (Pop-J) in the Siberian populations and from 0.60 (Pop-R) to 0.81 (Pop-Q) in the Carpathian populations. The average genetic diversity $(h)$ of the ten analyzed cpSSR loci in the Siberian and the Carpathian populations of Scots pine was 0.42 . The results showed that the ten cpSSR loci used in this study had high polymorphism in the Scots pine populations from Middle Siberia and the Romanian Carpathians. 
Table 2. Diversity indices for each SSR marker across 190 Scots pine individuals.

\begin{tabular}{cccccc}
\hline ID & Na & Ne & $I$ & $H$ & Nm \\
\hline PCP36567 & 3 & 1.83 & 0.78 & 0.45 & 3.64 \\
PCP48256 & 3 & 1.82 & 0.69 & 0.45 & 2.04 \\
PCP41131 & 5 & 1.25 & 0.46 & 0.20 & 3.92 \\
PCP30277 & 6 & 2.73 & 1.27 & 0.63 & 2.60 \\
PCP26106 & 3 & 1.66 & 0.71 & 0.40 & 3.60 \\
PCP45071 & 7 & 2.31 & 1.08 & 0.57 & 3.78 \\
Pt1254 & 5 & 1.63 & 0.79 & 0.39 & 2.61 \\
Pt15169 & 6 & 3.97 & 1.53 & 0.75 & 2.95 \\
Pt71936 & 7 & 3.08 & 1.39 & 0.67 & 2.74 \\
Pt87268 & 4 & 1.58 & 0.71 & 0.37 & 6.16 \\
Mean & 4.9 & 2.19 & 0.94 & 0.49 & 3.40 \\
SD & 1.60 & 0.84 & 0.35 & 0.17 & 0.38 \\
\hline
\end{tabular}

Note: Observed number of alleles per locus ( $\mathrm{Na}$ ); Mean number of effective alleles $(\mathrm{Ne})$; Shannon's Information index $(I)$; Nei's gene diversity index $(H)$; Gene flow $(\mathrm{Nm})$; SD-standard deviation.

Table 3. Genetic diversity of Scots pine populations in Middle Siberia and the Romanian Carpathians based on chloroplast microsatellite loci.

\begin{tabular}{cccccc}
\hline Population & $N$ & Na & Ne & $I$ & $h$ \\
\hline Middle Siberia & & & & & \\
Pop-A & 10 & $2.30( \pm 0.40)$ & $2.02( \pm 0.35)$ & $0.63( \pm 0.16)$ & $0.39( \pm 0.08)$ \\
Pop-B & 10 & $2.80( \pm 0.33)$ & $2.14( \pm 0.33)$ & $0.78( \pm 0.12)$ & $0.46( \pm 0.06)$ \\
Pop-C & 10 & $2.70( \pm 0.26)$ & $1.92( \pm 0.27)$ & $0.70( \pm 0.12)$ & $0.40( \pm 0.06)$ \\
Pop-D & 10 & $2.50( \pm 0.22)$ & $1.85( \pm 0.16)$ & $0.70( \pm 0.08)$ & $0.43( \pm 0.05)$ \\
Pop-E & 10 & $2.50( \pm 0.37)$ & $1.96( \pm 0.27)$ & $0.66( \pm 0.15)$ & $0.39( \pm 0.09)$ \\
Pop-F & 10 & $2.80( \pm 0.33)$ & $1.99( \pm 0.18)$ & $0.77( \pm 0.11)$ & $0.45( \pm 0.06)$ \\
Pop-G & 10 & $2.90( \pm 0.38)$ & $2.06( \pm 0.29)$ & $0.77( \pm 0.12)$ & $0.44( \pm 0.06)$ \\
Pop-H & 10 & $2.60( \pm 0.34)$ & $1.80( \pm 0.15)$ & $0.65( \pm 0.13)$ & $0.37( \pm 0.07)$ \\
Pop-I & 10 & $2.70( \pm 0.21)$ & $2.08( \pm 0.20)$ & $0.78( \pm 0.10)$ & $0.47( \pm 0.06)$ \\
Pop-J & 10 & $3.00( \pm 0.37)$ & $2.35( \pm 0.30)$ & $0.88( \pm 0.12)$ & $0.51( \pm 0.06)$ \\
Pop-K & 10 & $2.90( \pm 0.35)$ & $2.11( \pm 0.27)$ & $0.81( \pm 0.11)$ & $0.47( \pm 0.05)$ \\
Pop-L & 10 & $2.30( \pm 0.21)$ & $1.54( \pm 0.14)$ & $0.53( \pm 0.10)$ & $0.31( \pm 0.06)$ \\
Pop-M & 10 & $2.70( \pm 0.15)$ & $2.06( \pm 0.15)$ & $0.80( \pm 0.07)$ & $0.49( \pm 0.04)$ \\
Pop-N & 10 & $1.80( \pm 0.20)$ & $1.41( \pm 0.12)$ & $0.38( \pm 0.10)$ & $0.24( \pm 0.06)$ \\
Pop-O & 10 & $3.10( \pm 0.28)$ & $2.03( \pm 0.17)$ & $0.83( \pm 0.09)$ & $0.47( \pm 0.05)$ \\
Overall Mean & & $2.64( \pm 0.29)$ & $1.95( \pm 0.22)$ & $0.71( \pm 0.11)$ & $0.42( \pm 0.06)$ \\
Romanian Carpathians & & & & & \\
Pop-P & 10 & $2.80( \pm 0.36)$ & $2.17( \pm 0.27)$ & $0.78( \pm 0.15)$ & $0.45( \pm 0.08)$ \\
Pop-Q & 10 & $3.30( \pm 0.50)$ & $2.16( \pm 0.35)$ & $0.81( \pm 0.17)$ & $0.43( \pm 0.08)$ \\
Pop-R & 10 & $2.30( \pm 0.42)$ & $1.97( \pm 0.37)$ & $0.60( \pm 0.17)$ & $0.35( \pm 0.09)$ \\
Pop-S & 10 & $2.50( \pm 0.31)$ & $2.00( \pm 0.19)$ & $0.73( \pm 0.10)$ & $0.46( \pm 0.05)$ \\
Overall Mean & & $2.73( \pm 0.40)$ & $2.08( \pm 0.30)$ & $0.73( \pm 0.15)$ & $0.42( \pm 0.08)$ \\
\hline
\end{tabular}

Note: Sample size $(\mathrm{N})$; Mean number of alleles per locus (Na); Number of effective alleles $(\mathrm{Ne})$; Shannon's Information Index $(I)$; Haploid genetic diversity $(h) ; \pm$ standard errors in parentheses.

\subsection{Chloroplast DNA Haplotype Variation}

The cpSSR analysis of 190 individuals of Scots pine yielded a total of 158 haplotypes. The majority of the haplotypes (85\%) were detected only once (unique haplotypes). The four Carpathian and three Siberian populations of Scots pine (Pop-C/Chunoyar, PopG/Zeledeevo and Pop-H/Uyar) were characterized by the highest number of private haplotypes (nine), while the lowest number (five) of private haplotypes was recorded in two Siberian populations (Pop-F/Sukhobuzimskoye_1 and Pop-N/Balgazyn_1 populations) (Table 4). 
Table 4. Statistical characteristics of cpSSR haplotypes for 19 Scots pine populations.

\begin{tabular}{lccccc}
\hline Population & $\boldsymbol{A}$ & $\boldsymbol{P}$ & $\boldsymbol{N}_{\mathbf{E}}$ & $\boldsymbol{H}_{\mathbf{C P}}$ & $\boldsymbol{D}_{\text {sh }}$ \\
\hline & \multicolumn{5}{c}{ Middle Siberia } \\
Pop-A & 10 & 7 & 10.00 & 1.00 & 4.17 \\
Pop-B & 10 & 7 & 10.00 & 1.00 & 5.32 \\
Pop-C & 10 & 9 & 10.00 & 1.00 & 4.38 \\
Pop-D & 8 & 6 & 7.14 & 0.96 & 4.47 \\
Pop-E & 10 & 6 & 10.00 & 1.00 & 5.02 \\
Pop-F & 9 & 5 & 8.33 & 0.98 & 5.43 \\
Pop-G & 10 & 9 & 10.00 & 1.00 & 4.32 \\
Pop-H & 10 & 9 & 10.00 & 1.00 & 3.72 \\
Pop-I & 10 & 8 & 10.00 & 1.00 & 4.41 \\
Pop-J & 10 & 6 & 10.00 & 1.00 & 7.52 \\
Pop-K & 10 & 8 & 10.00 & 1.00 & 5.18 \\
Pop-L & 9 & 6 & 8.33 & 0.98 & 1.90 \\
Pop-M & 10 & 7 & 10.00 & 1.00 & 4.41 \\
Pop-N & 7 & 5 & 5.56 & 0.91 & 0.98 \\
Pop-O & 9 & 7 & 8.33 & 0.98 & 5.96 \\
Mean & 9.47 & 7.00 & 9.18 & 0.99 & 4.48 \\
Pop-P & 10 & Romanian Carpathians & & \\
Pop-Q & 10 & 9 & 10.00 & 1.00 & 7.55 \\
Pop-R & 10 & 9 & 10.00 & 1.00 & 6.59 \\
Pop-S & 9 & 9 & 10.00 & 1.00 & 3.97 \\
Mean & 9.75 & 9 & 8.33 & 0.97 & 5.11 \\
Non & 9.00 & 9.58 & 0.99 & 5.81
\end{tabular}

Note: Number of haplotypes $(A)$; Number of private haplotypes $(P)$; Effective number of haplotypes $\left(N_{\mathrm{E}}\right)$; Haplotype diversity $\left(H_{\mathrm{CP}}\right)$; Mean genetic distance between individuals $\left(D^{2} \mathrm{sh}\right)$.

Haplotype H112 is common to six of the studied populations (Pop-A/Vanavara_2, Pop-E/Sukhobuzimskoye_2, Pop-F/Sukhobuzimskoye_1, Pop-H/Uyar, Pop-K/Sarala_2, Pop-N/Balgazyn_1) that were located in taiga, forest-steppe, and Southern Siberian mountain zones in Middle Siberia (Figure 2). The frequency of the H112 haplotype is the highest in the Pop-N/Balgazyn_1 population (30\%) (Table S1). Two haplotypes, H64 and H122, are common to three Siberian populations and eleven haplotypes are common to two populations that were located in the same geographical region. Only three common haplotypes (H86, H107, H118) were found in two Siberian (Pop-J and Pop-O) and three Carpathian populations of Scots pine (Pop-P, Pop-Q and Pop-R). High values of haplotype diversity $\left(H_{\mathrm{CP}}=0.91-1\right)$ were revealed within all studied populations (Table 4$)$. The effective number of haplotypes varied from 5.56 to 10 and the mean genetic distance between individuals ranged from 0.98 (Pop-N/Balgazyn_1) to 7.55 (Pop-P/Poiana Stampei).

\subsection{Population Genetic Structure of Scots Pine}

The values of Nei's genetic distance among populations ranged from 0.0032 (Pop-J/Pop-K) to 0.2441 (Pop-B/Pop-P) (Table S2). UPGMA clustering showed that two groups were separated at the population level (Figure 3). The first group consisted of fifteen Middle Siberian populations and the second group was composed of four Carpathian populations.

The hierarchical analysis of molecular variance (AMOVA) showed that the variation among two geographic regions (Middle Siberia and Carpathian Mountains) accounted for $5 \%$ of the total variance. The variance among populations within regions was $3 \%(p<0.01)$. The AMOVA performed within the Siberian populations of Scots pine showed a lower differentiation among populations ( $\mathrm{PhiPT}=3 \%, p<0.05$ ) when compared to the Carpathian populations $(\mathrm{PhiPT}=6 \% ; p<0.01)($ Table 5$)$. 


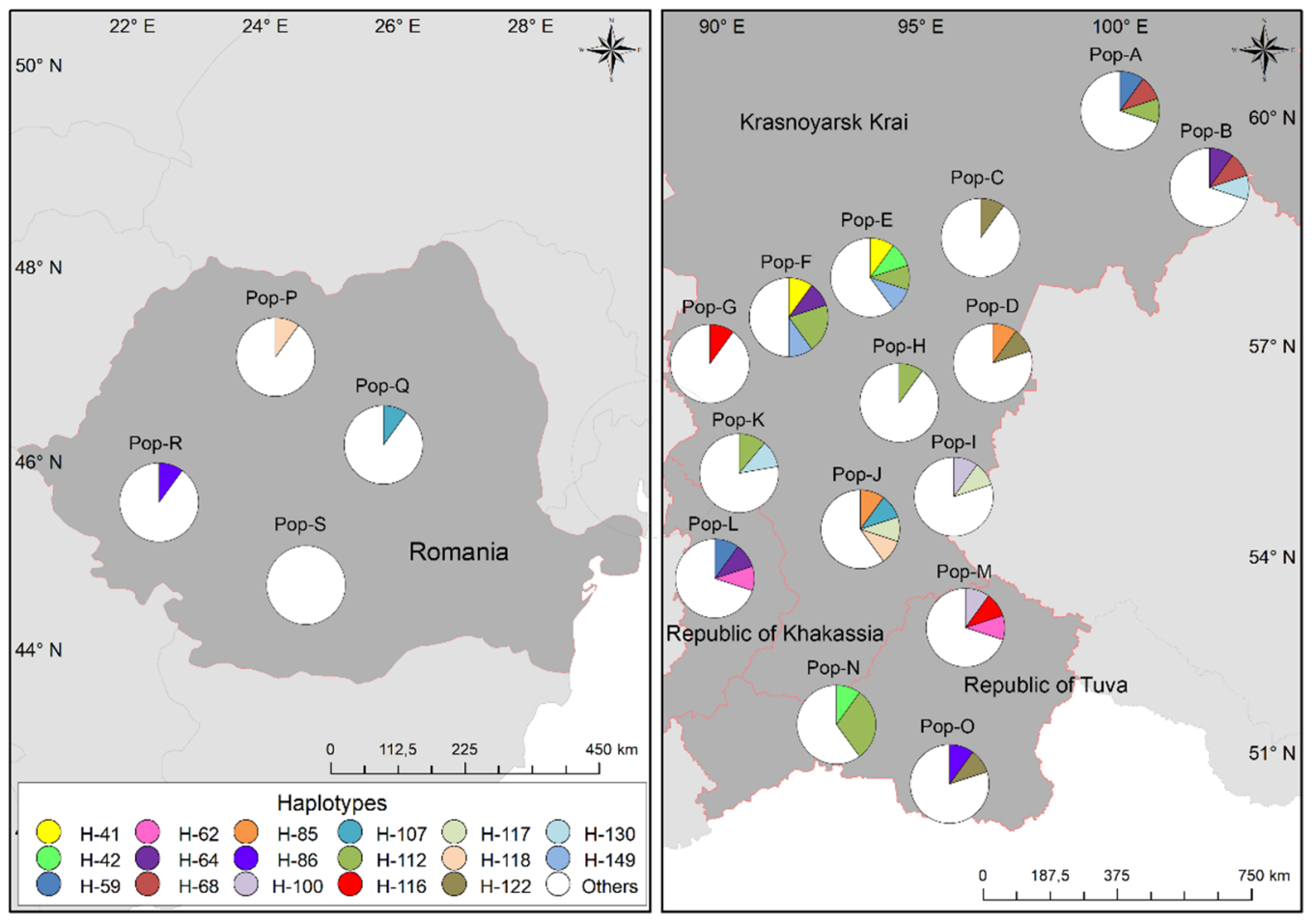

Figure 2. Geographic distribution of the 17 common chloroplast DNA haplotypes in 19 Scots pine populations (for the abbreviations, see Table 1) studied in Middle Siberia and the Romanian Carpathians (Table S1).

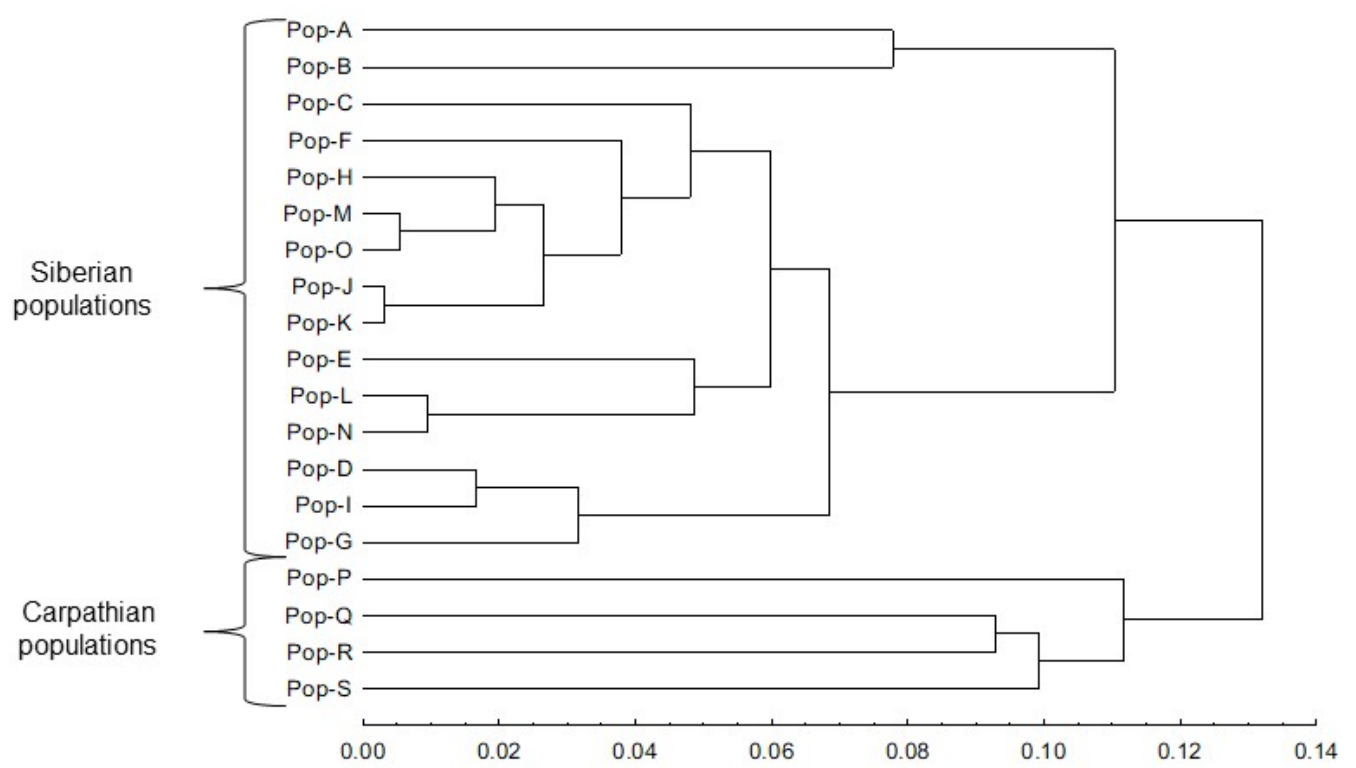

Figure 3. UPGMA dendrogram based on Nei's genetic distances among populations of Scots pine.

The population structure analysis of the Siberian and Carpathian populations of Scots pine showed that $\Delta \mathrm{K}$ was the highest when $\mathrm{K}=3$ (Figure 4). All individual trees showed admixture from three genetic clusters. For $K=3$, the Siberian populations had a larger membership in cluster 3 (blue color) than the Carpathian populations. The membership in cluster 1 (red color) was higher in the case of the Carpathian populations (Figure 1). 
Table 5. Hierarchical analysis of molecular variance (AMOVA).

\begin{tabular}{|c|c|c|c|c|c|}
\hline Source of Variation & d.f. & $\begin{array}{l}\text { Sum of } \\
\text { Squares }\end{array}$ & $\begin{array}{c}\text { Variance } \\
\text { Components }\end{array}$ & $\begin{array}{l}\text { Percentage } \\
\text { of Variation }\end{array}$ & $p$ \\
\hline Among regions & 1 & 10.829 & 0.121 & 5 & \multirow{4}{*}{$<0.01$} \\
\hline Among populations & 17 & 54.113 & 0.085 & 3 & \\
\hline Within populations & 171 & 398.900 & 2.333 & 92 & \\
\hline Total & 189 & 463.842 & 2.539 & 100 & \\
\hline \multicolumn{6}{|c|}{ Siberian populations } \\
\hline Among populations & 14 & $88.880^{1}$ & 0.147 & 3 & \multirow{3}{*}{$<0.05$} \\
\hline $\begin{array}{l}\text { Among individuals } \\
\text { Within populations }\end{array}$ & 135 & 659.000 & 4.881 & 97 & \\
\hline Total & 149 & 747.880 & 5.028 & 100 & \\
\hline \multicolumn{6}{|c|}{ Carpathian populations } \\
\hline Among populations & 3 & 11.600 & 0.153 & 6 & \multirow{3}{*}{$<0.01$} \\
\hline $\begin{array}{l}\text { Among individuals } \\
\text { Within populations }\end{array}$ & 36 & 84.200 & 2.339 & 94 & \\
\hline Total & 39 & 95.800 & 2.492 & 100 & \\
\hline
\end{tabular}

Note: Degrees of freedom (d.f.); Probability $(p)$.

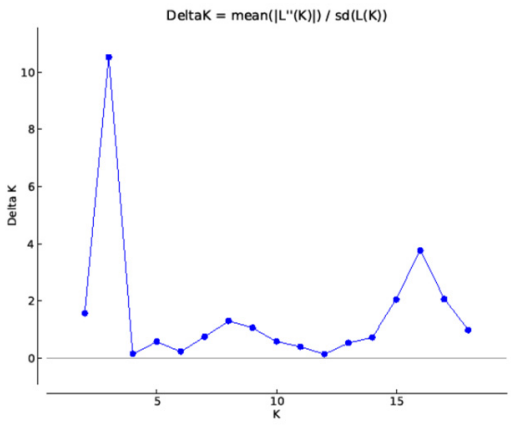

(A)

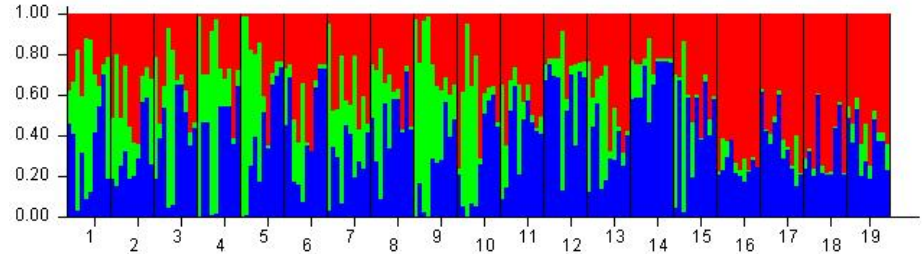

(B)

Figure 4. Population genetic structure of 19 Scots pine populations in Middle Siberia (Pop 1-15) and the Romanian Carpathians (Pop 16-19). (A) Estimation of the best subpopulation numbers based on appropriate $\mathrm{K}$ value: the mean $\Delta \mathrm{K}$ values among the 10 runs reached a maximum at $K=3$. (B) Structure clustering results obtained for three genetic clusters (Populations are numbered 1-19 as in Table 1).

We further analyzed the correlation between genetic distance and geographic distance for the studied populations using the Mantel test. The results showed a low but significant correlation between genetic differentiation and geographical distance among Siberian populations $\left(R^{2}=0.1746, p<0.01\right)$ and there was no significant correlation between genetic distance and geographic distance among Carpathian populations $\left(R^{2}=0.0059, p>0.05\right)$.

\section{Discussion}

The genetic diversity and differentiation of Scots pine populations from different forest zones in Middle Siberia and the Romanian Carpathians were assessed based on the polymorphism of ten cPSSR markers. Our results suggest a high genetic diversity $\left(H_{\mathrm{CP}}=0.91-1.00\right)$ in all Scots pine populations and are in line with other regional studies on Scots pine in Europe and Asia [5,21,29]. Nonetheless, in the present study, the four relict pine populations from the Carpathian region were characterized by a relatively higher level of genetic diversity, i.e., the number of alleles and haplotypes, the number of private haplotypes, the effective number of haplotypes, and the mean genetic distance between individuals within the population. The higher level of genetic diversity in the Carpathian populations might be a consequence of the interglacial and postglacial evolutionary history of Scots pine in Southeastern Europe. The existence of glacial refugia in the Carpathian 
Mountains and an admixture of phylogenetic lineages may explain a higher level of genetic diversity in this region [7].

In Middle Siberia, the two northernmost populations showed a slightly higher haplotype diversity $\left(H_{\mathrm{CP}}=1.00\right)$ than the two southernmost populations $\left(H_{\mathrm{CP}}=0.91\right.$ and $H_{\mathrm{CP}}=0.98$, respectively) (Table 4$)$. A similar trend has also been reported for Scots pine populations from Fennoscandia, which showed a higher haplotype diversity $\left(H_{\mathrm{CP}}=0.807\right)$ than those from the south European populations $\left(H_{\mathrm{CP}}=0.750\right)$ [4]. Such patterns of genetic diversity may result from peculiarities of post-glacial history of the species, such as the mixing of different refugial lineages [4]. Among the Siberian pine populations, the highest number of private haplotypes was detected in the populations from the core distribution area (Pop-G/Zeledeevo, Pop-H/Uyar and Pop-C/Chunoyar). The process of colonization might trigger new genetic variants for neutral genetic diversity in these populations [4]. The lowest haplotype number (seven) was detected in the Pop-N/Balgazyn_1 population, which refers to the southernmost pine forest of Northern Asia. The Balgazyn pine forest belongs to the category of valuable forests in terms of its species composition, productivity, and genetic quality, as well as performing particularly important protective functions in sharply continental climate [44]. Moreover, it is considered as a Holocene relic and, currently, is of a high conservation priority [45]. Interestingly, another population PopO/Balgazyn_2, which refers to the same pine forest, showed a higher haplotype number (nine). Such discrepancy between adjacent populations located at a relatively small geographical distance $(21 \mathrm{~km}$ ) may result from large natural disturbances (forest fires), which occurred in Pop-N population between 1988 and 2014 [44,45]. Local fires may be the cause of the reduction in the haplotype number observed in Pop-N. Decrease of population size, due to fires, logging, pest and diseases, and environmental pollution may lead to a decline in genetic diversity [46,47]. Another explanation would be the relatively small sample size (10 individuals per population).

AMOVA showed a low level of genetic structure (PhiPT $=3 \%$ ) among the fifteen Siberian populations, even though they are scattered over large distances of more than $1000 \mathrm{~km}$. In contrast, the genetic variation among the four relict Carpathian populations accounted for $6 \%$ of the total variance, although the geographic distances among them are much smaller. More significant geographic barriers among the Carpathian populations than among the Siberian ones may have contributed to a higher level of genetic differentiation. However, the low overall genetic differentiation among the Scots pine populations obtained in this study is consistent with previous reports in P. sylvestris using chloroplast markers [5,29]. Low values of the PhiPT $(0.41-1.7 \%)$ were also detected by Semerikov et al. [21] between 38 Scots pine populations from Asia and the European part of Russia. Based on STRUCTURE analysis, three clusters were defined in the Siberian and the Carpathian populations of Scots pine where each individual was comprised of three genetic groups, showing a weak genetic structure between the two geographic regions, which is consistent with the grouping revealed by the UPGMA dendrogram.

There was a weak positive correlation between the genetic and geographic distances for the analyzed populations of Scots pine in Middle Siberia. Pine species are efficient in pollen dispersal, resulting in a low overall population structure and differentiation $[8,48]$. Furthermore, considering the large geographical areas covered by the investigated populations in Middle Siberia, it seems that their genetic similarity results from a shared phylogeographic history. Additionally, this can also be confirmed by a widespread occurrence of the H112 haplotype across the Siberian populations. Moreover, three common haplotypes were detected in the Carpathian and the Siberian populations of Scots pine. The presence of common haplotypes in two geographical regions located far away from each other may also suggest a common origin of the Siberian and Carpathian pine populations. However, this is highly unlikely; extensive gene flow over large distances via pollen may be the most likely hypothesis.

Our findings, based on chloroplast DNA analysis, indicate that a high genetic diversity of individuals exists in Scots pine populations from Middle Siberia and the Romanian 
Carpathians and that, despite large geographic distances and barriers, there is limited genetic differentiation.

\section{Conclusions}

In the present study, ten cPSSR markers were employed to estimate the genetic diversity within and among nineteen natural populations of Scots pine in Middle Siberia and the Romanian Carpathians. All populations showed high levels of genetic diversity. However, one of the southernmost Siberian populations showed the lowest level of haplotype diversity. Accordingly, the performance of this population should be the focus of long-term study, aimed at the monitoring of population dynamics. Three common haplotypes were found among the Siberian and the Carpathian populations, which can be explained by very efficient long-distance gene flow or common ancestry. A weak genetic structure between the two geographic regions was revealed. Our study may contribute to the development of a strategy of sustainable management of Scots pine genetic resources in Middle Siberia and the Romanian Carpathians.

Supplementary Materials: The following are available online at https:/ /www.mdpi.com/article/10 $.3390 / \mathrm{f} 12121757 / \mathrm{s} 1$, Table S1: Frequency of the 17 common haplotypes within Scots pine populations, Table S2: Nei's genetic distances of 19 Scots pine populations.

Author Contributions: Conceptualization, A.L.C. and M.S.; methodology, E.C. and A.L.C.; software, E.C., M.S. and A.I.; validation, E.C.; formal analysis, M.S.; investigation, M.S., E.C. and A.L.C.; resources, P.M., S.K., N.K. and M.S.; data curation, M.S.; writing—original draft preparation, M.S.; writing - review and editing, A.L.C.; visualization, M.S. and T.S.; supervision, A.L.C.; project administration, M.S.; funding acquisition, P.M. All authors have read and agreed to the published version of the manuscript.

Funding: The research was carried out within the State Assignment (theme «Fundamental principles of forest protection from entomo- and phyto- pests in Siberia» No. FEFE 2020-0014) supported by the Ministry of Education and Science of the Russian Federation.

Institutional Review Board Statement: Not applicable.

Informed Consent Statement: Not applicable.

Data Availability Statement: Data is contained within the article or supplementary material.

Conflicts of Interest: The authors declare no conflict of interest.

\section{References}

1. FAO. The State of the World's Forest Genetic Resources. Commission on Genetic Resources for Food and Agriculture; FAO: Rome, Italy, 2014; p. 276.

2. Altukhov, Y.P. Dynamics of gene pools under anthropogenic influences. Vestn. VOGiS 2004, 8, 40-59.

3. Naydenov, K.; Senneville, S.; Beaulieu, J.; Tremblay, F.; Bousquet, J. Glacial vicariance in Eurasia: Mitochondrial DNA evidence from scots pine for a complex heritage involving genetically distinct refugia at mid-northern latitudes and in Asia Minor. BMC Evol. Biol. 2007, 7, 233. [CrossRef]

4. Dering, M.; Kosiński, P.; Wyka, T.P.; Pers-Kamczyc, E.; Boratyński, A.; Boratyńska, K.; Reich, P.B.; Romo, A.; Zadworny, M.; Żytkowiak, R.; et al. Tertiary remnants and Holocene colonizers: Genetic structure and phylogeography of Scots pine reveal higher genetic diversity in young boreal than in relict Mediterranean populations and a dual colonization of Fennoscandia. Divers. Distrib. 2017, 23, 540-555. [CrossRef]

5. Robledo-Arnuncio, J.J.; Collada, C.; Alia, R.; Gil, L. Genetic structure of montane isolates of Pinus sylvestris L. in a Mediterranean refugial area. J. Biogeogr. 2005, 32, 595-605. [CrossRef]

6. Sebastiani, F.; Pinzauti, F.; Kujala, S.T.; González-Martínez, S.C.; Vendramin, G.G. Novel polymorphic nuclear microsatellite markers for Pinus sylvestris L. Conserv. Genet. Resour. 2012, 4, 231-234. [CrossRef]

7. Şofletea, N.; Mihai, G.; Ciocîrlan, E.; Curtu, A.L. Genetic Diversity and Spatial Genetic Structure in Isolated Scots Pine (Pinus sylvestris L.) Populations Native to Eastern and Southern Carpathians. Forests 2020, 11, 1047. [CrossRef]

8. Olsson, J. Genetic Diversity and Hardiness in Scots Pine from Scandinavia to Russia. Master's Thesis, Umeå University, Umeå, Sweden, 2019.

9. FAO. The Russian Federation Forest Sector. Outlook Study to 2030; FAO: Rome, Italy, 2012; p. 84.

10. Sannikov, S.N.; Petrova, I.V. Differentiation of Scots Pine Populations; UB RAS: Yekaterinburg, Russia, 2003 ; p. 247. 
11. Milyutin, L.I.; Novikova, T.N.; Tarakanov, V.V.; Tikhonova, I.V. Scots Pine in Steppe and Forest-Steppe Pine Forests of Siberia; Academic Publishing House "Geo": Novosibirsk, Russia, 2013; p. 127.

12. Pimenov, A.V. Biodiversity of the Scots Pine (Pinus sylvestris L.) in Contrasting Ecotopes of the South of Siberia. Ph.D. Thesis, Siberian Branch of the Russian Academy of Sciences, Krasnoyarsk, Russia, 2015.

13. Ilyinov, A.A.; Raevsky, B.V. The current state of Pinus sylvestris L. gene pool in Karelia. Sib. J. For. Sci. 2016, 5, 45-54.

14. Torbik, D.N.; Bedrickaya, T.V.; Vlasova, M.M.; Sinelnikov, I.G. Genetic Diversity of Natural Populations of Pinus sylvestris; Northern Research Institute of Forestry: Arkhangelsk, Russia, 2019; pp. 91-99.

15. Filonenko, V. There are fewer coniferous forests in Russia. Parliamentary Newspaper, 19 October 2021 ; p. 39.

16. Urbaniak, L.; Wojnicka-Półtorak, A.; Celiński, K.; Lesiczka, P.; Pawlaczyk, E. Genetic resources of relict populations of Pinus sylvestris (L.) in Western Carpathians assessed by chloroplast microsatellites. Biologia 2019, 74, 1077-1086. [CrossRef]

17. Blanc-Jolivet, C.; Yanbaev, Y.; Kersten, B.; Degen, B. A set of SNP markers for timber tracking of Larix spp. in Europe and Russia. Forestry 2018, 91, 614-628. [CrossRef]

18. Rai, K.C.; Ginwal, H.S. Microsatellite analysis to study genetic diversity in Khasi Pine (Pinus Kesiya Royle Ex. Gordon) using chloroplast SSR markers. Silvae Genet. 2018, 67, 99-105. [CrossRef]

19. Semerikov, V.L.; Semerikova, S.A.; Putintseva, Y.A.; Tarakanov, V.V.; Tikhonova, I.V.; Vidyakin, A.I.; Oreshkova, N.V.; Krutovsky, K.V. Colonization history of Scots pine in Eastern Europe and North Asia based on mitochondrial DNA variation. Tree Genet. Genomes 2018, 14, 8. [CrossRef]

20. Stojnić, S.; Avramidou, E.V.; Fussi, B.; Westergren, M.; Orlović, S.; Matović, B.; Trudić, B.; Kraigher, H.; AAravanopoulos, F.; Konnert, M. Assessment of Genetic Diversity and Population Genetic Structure of Norway Spruce (Picea abies (L.) Karsten) at Its Southern Lineage in Europe. Implications for Conservation of Forest Genetic Resources. Forests 2019, 10, 258. [CrossRef]

21. Semerikov, V.L.; Semerikova, S.A.; Dymshakova, O.S.; Zatsepina, K.G.; Tarakanov, V.V.; Tikhonova, I.V.; Ekart, A.K.; Vidyakin, A.I.; Jamiyansuren, S.; Rogovtsev, R.V.; et al. Microsatellite loci polymorphism of chloroplast DNA of scots pine (Pinus sylvestris L.) in Asia and Eastern Europe. Russ. J. Genet. 2014, 50, 577-585. [CrossRef]

22. Naydenov, D.K.; Naydenov, M.K.; Alexandrov, A.; Vasilevski, K.; Gyuleva, V.; Matevski, V.; Nikolic, B.; Goudiaby, V.; Bogunić, F.; Paitaridou, D.; et al. Ancient split of major genetic lineages of European Black Pine: Evidence from chloroplast DNA. Tree Genet. Genomes 2016, 14, 68. [CrossRef]

23. Bilgen, B.B.; Nuray, K. Genetic diversity among Pinus sylvestris L. populations and its implications for genetic conservation: Comparison of nuclear and chloroplast microsatellite markers. Fresenius Environ. Bull. 2017, 26, 6873-6881.

24. Hebda, A.; Wójkiewicz, B.; Wachowiak, W. Genetic characteristics of Scots pine in Poland and reference populations based on nuclear and chloroplast microsatellite markers. Silva Fenn. 2017, 2, 17. [CrossRef]

25. Naydenov, K.D.; Naydenov, M.K.; Alexandrov, A.; Vasilevski, K.; Hinkov, G.; Matevski, V.; Nikolic, B.; Goudiaby, V.; Riegert, D.; Paitaridou, D.; et al. Ancient genetic bottleneck and Plio-Pleistocene climatic changes imprinted the phylobiogeography of European Black Pine populations. Eur. J. Res. 2017, 136, 767-786. [CrossRef]

26. Toth, E.G.; Vendramin, G.G.; Bagnoli, F.; Cseke, K.; Höhn, M. High genetic diversity and distinct origin of recently fragmented Scots pine (Pinus sylvestris L.) populations along the Carpathians and the Pannonian Basin. Tree Genet. Genomes 2017, 13, 47. [CrossRef]

27. Cui, B.; Deng, P.; Zhang, S.; Zhao, Z. Genetic Diversity and Population Genetic Structure of Ancient Platycladus orientalis L. (Cupressaceae) in the Middle Reaches of the Yellow River by Chloroplast Microsatellite Markers. Forests 2021, 12, 592. [CrossRef]

28. Vendramin, G.G.; Lelli, L.; Rossi, P.; Morgante, M. A set of primers for the amplification of 20 chloroplast microsatellites in Pinaceae. Mol. Ecol. 1996, 5, 111-114. [CrossRef] [PubMed]

29. Provan, J.; Soranzo, N.; Wilson, N.J.; McNicol, J.W.; Forrest, G.I.; Cottrell, J.; Powell, W. Gene-pool variation in Caledonian and European Scots pine (Pinus sylvestris L.) revealed by chloroplast simple-sequence repeats. R. Soc. 1998, 265, 1697-1705. [CrossRef]

30. Ribeiro, M.M.; Mariette, S.; Vendramin, G.G.; Szmidt, A.E.; Plomion, C.; Kremer, A. Comparison of genetic diversity estimates within and among populations of maritime pine using chloroplast simple-sequence repeat and amplified fragment length polymorphism data. Mol. Ecol. 2002, 11, 869-877. [CrossRef]

31. Wojnicka-Półtorak, A.; Celiński, K.; Chudzińska, E. Genetic diversity among age classes of a Pinus sylvestris (L.) population from the Białowieża primeval Forest, Poland. Forests 2017, 8, 227. [CrossRef]

32. Bernhardsson, C.; Floran, V.; Ganea, S.L.; García-Gil, M.R. Present genetic structure is congruent with the common origin of distant Scots pine populations in its Romanian distribution. For. Ecol. Manag. 2016, 361, 131-143. [CrossRef]

33. Chybicki, I.; Dzialuk, A.; Trojankiewicz, M.; Slawski, M.; Burczyk, J. Spatial Genetic Structure within Two Contrasting Stands of Scots Pine (Pinus sylvestris L.). Silvae Genet. 2017, 57, 193-202. [CrossRef]

34. Kodeks, C. Approval of the List of Areas of Forest Growth and Forest Areas of the Russian Federation; Order No. 367 (18 Aug 2014 ); Ministry of Natural Resources and the Environment: Moscow, Russian, 2020.

35. Doyle, J.J.; Doyle, J.L. Isolation of plant DNA from fresh tissue. Focus 1990, 12, 13-15.

36. Yeh, F.C.; Yang, R.C.; Boyle, T. POPGENE Version 1.32 Microsoft Windows-Based Freeware for Populations Genetic Analysis; University of Alberta: Edmonton, AB, Canada, 1999.

37. Peakall, R.; Smouse, P.E. GenAlEx 6: Genetic analysis in Excel. Population genetic software for teaching and research. Mol. Ecol. Notes 2006, 6, 288-295. [CrossRef] 
38. Eliades, N.-G.; Eliades, D.G. HAPLOTYPE ANALYSIS: Software for Analysis of Haplotypes Data. Distributed by the Authors. Forest Genetics and Forest Tree Breeding; Georg-Augst University Goettingen: Göttingen, Germany, 2009; p. 18.

39. Nei, M. Estimation of average heterozygosity and genetic distance from a small number of individuals. Genetics 1978, 89, 583-590. [CrossRef]

40. Weiß, C.H. StatSoft, Inc., Tulsa, OK.: STATISTICA, Version 8. Asta Adv. Stat. Anal. 2007, 91, 339-341. [CrossRef]

41. Pritchard, J.; Stephens, M.; Donnelly, P. Inference of population structure using multilocus genotype data. Genetics 2000, 155, 945-959. [CrossRef]

42. Earl, D.A.; Vonholdt, B.M. Structure Harvester: A website and program for visualizing Structure output and implementing the Evanno method. Conserv. Genet. Resour. 2012, 4, 359-361. [CrossRef]

43. Evanno, G.; Regnaut, S.; Goudet, J. Detecting the number of clusters of individuals using the software Structure: A simulation study. Mol. Ecol. 2005, 14, 2611-2620. [CrossRef] [PubMed]

44. Kuular, K.B.; Namzyn, A. Climatology and anthropogeny dynamics of Balgazyn ribbon pine forest. Interexpo Geo-Sib. 2015, 4, 25-28.

45. Kuzhuget, S.K. Forest landscape-Balgazyn ribbon pine forest. Sci. Time 2014, 11, 163-166.

46. Ellstrand, N.C.; Elam, D.R. Population genetic consequences of small population size: Implications for plant conservation. Annu. Rev. Ecol. Syst. 1993, 24, 217-242. [CrossRef]

47. Prishnivskaya, Y.; Nassonova, E.; Vasileva, Y.; Boronnikova, S. Selecting of Polymorphic Loci of Genome for Identification of Populations of Pinus sylvestris L. on East-Europe Plain. Bull. Sci. Pract. 2019, 5, 25-30. [CrossRef]

48. Petit, R.J.; Duminil, J.; Fineschi, S.; Hampe, A.; Salvini, D.; Vendramin, G.G. Comparative organization of chloroplast, mitochondrial and nuclear diversity in plant populations. Mol. Ecol. 2005, 14, 689-701. [CrossRef] [PubMed] 